\title{
Mekanisasi Usahatani Padi Di Kecamatan Sananwetan Kota Blitar
}

\author{
Cristina Ratnawati \\ Magister Agribisnis, Universitas Islam Kadiri \\ Email : cristinaratna7@gmail.com
}

\begin{abstract}
This research purposes for determining the use of agricultural mechanization and its impact on rice farming in Sidomulyo Gapoktan, of Sananwetan District of Blitar City, which is expected to improve the living standards and welfare of its group members. The total samples which taken were 50 rice farmers of Sidomulyo Gapoktan in Sananwetan District of Blitar City. The sampling taken using purposive random sampling technique, which is deliberately chosed based on criteria which determined by the researcher. The Data analysis was carried out descriptively, using the Mann-Whitney Test and the Multiple Linear Regression Cobb Douglas model. Based on the results of the study, it was found that the mechanization of rice farming in Sidomulyo Gapoktan, Sananwetan District, Blitar City has not still optimal. This is caused by the farmers' perceptions of the results of unsatisfactory performance of agricultural machinery, a sense of humanity towards' farm labors, narrow area of farming and insufficient availability of agricultural machinery. The result of reseach which was used Mann-Whitney Test analysis, found that pesticide using and labor requirements were smaller and differed significantly in the use of full mechanization rather than partial mechanization. Harvest variable costs were lower in the use of full mechanization and were significantly different than using partial mechanisms. The Productivity of rice in full mechanization is $782,15 \mathrm{~kg} / 1000 \mathrm{~m} 2$ while in partial mechanization was $682.87 \mathrm{~kg} /$ $1000 \mathrm{~m} 2$. For farmers' income in full mechanization is Rp. 1,153,407, - per $1000 \mathrm{m2}$, in partial mechanization of Rp. 1,590,574, - per 1000m2. Multiple Linear Regression Analysis of the Cobb Douglas model shows that the land area (m2), seed costs and the use of mechanization have a significant influence on the income of rice farming in Sananwetan District, Blitar City.

Keywords : rice farming, mechanization, Mann-Whitney Test, multiple linear regression
\end{abstract}

\section{Abstrak}

Penelitian ini bertujuan untuk mengetahui penggunaan mekanisasi pertanian dan dampaknya terhadap usahatani padi di Gapoktan Sidomulyo, Kecamatan Sananwetan, Kota Blitar, yang diharapkan dapat meningkatkan standar hidup dan kesejahteraan anggota kelompoknya. Jumlah sampel yang diambil adalah 50 petani padi di Kecamatan Sidokulyo Gapoktan Sananwetan, Kota Blitar. Pengambilan sampel menggunakan teknik purposive random sampling, yang dipilih secara sengaja berdasarkan kriteria yang ditentukan oleh peneliti. Analisis data dilakukan secara deskriptif, menggunakan Uji Mann-Whitney dan Regresi Linear Berganda model Cobb Douglas. Dari hasil penelitian didapatkan bahwa mekanisasi pertanian padi di Gapoktan Sidomulyo, Kecamatan Sananwetan, Kota Blitar masih belum optimal. Hal ini disebabkan karena persepsi petani terhadap hasil dari kinerja mesin pertanian yang tidak memuaskan, rasa kemanusiaan terhadap 'buruh tani', luas lahan yang sempit dan ketersediaan mesin pertanian yang tidak mencukupi. Dari hasil penelitian menggunakan analisis Uji Mann-Whitney, ditemukan bahwa penggunaan pestisida dan kebutuhan tenaga kerja lebih kecil dan berbeda secara signifikan pada penggunaan mekanisasi penuh daripada mekanisasi parsial. Biaya variabel panen lebih rendah pada penggunaan mekanisasi penuh dan secara signifikan berbeda dibandingkan dengan menggunakan mekanisme secara parsial. Produktivitas padi dalam mekanisasi penuh adalah $782,15 \mathrm{~kg} / 1000 \mathrm{~m} 2$ sedangkan pada mekanisasi parsial adalah $682,87 \mathrm{~kg} / 1000 \mathrm{~m} 2$. Untuk pendapatan petani pada mekanisasi penuh adalah Rp. 1.153.407, - per $1000 \mathrm{~m} 2$, dalam mekanisasi parsial Rp. 1.590.574, - per 1000m2. Analisis Regresi Linear Berganda 
model Cobb Douglas menunjukkan bahwa luas tanah (m2), biaya benih dan penggunaan mekanisasi memiliki pengaruh yang signifikan terhadap pendapatan usahatani padi di Kecamatan Sananwetan, Kota Blitar.

\section{Kata Kunci : Budidaya padi, mekanisasi, Uji Mann-Whitney, Regresi Linear Berganda}

\section{Pendahuluan}

Rencana Pembangunan Jangka Panjang (RPJP) Tahun 2005 - 2025 memuat tentang visi pembangunan nasional yaitu untuk mewujudkan Indonesia Yang Mandiri, Maju, Adil dan Makmur salah satunya ditempuh dengan pembangunan sumber daya manusia berkualitas dan berdaya saing; meningkatkan penguasaan dan pemanfaatan iptek dan penerapan menuju inovasi secara berkelanjuta, membangun infrastruktur yang maju dan memperkuat perekonomian domestik berbasis keunggulan setiap wilayah menuju keunggulan kompetitif dengan membangun keterkaitan sistem produksi, distribusi, dan pelayanan termasuk pelayanan jasa dalam negeri.

Pentingnya pertanian dalam kehidupan manusia ditunjukkan dengan besarnya permintaan untuk pangan, pakan dan biofuel pada tahun 2050 sehingga perlu dilakukannya upaya-upaya dalam peningkatan produksi agar supaya dapat memenuhi semakin meningkatnya permintaan sebagai salah satu akibat peningkatan populasi manusia. Sektor pertanian di sebagian besar negara berkembang merupakan sektor yang paling penting dalam perekonomian dunia. Namun pengalaman negara berkembang dengan peningkatan populasi yang konsisten, produksi pangan menurun karena terabaikannya sektor ini (Ajao, dkk., 2005).

Salah satu upaya untuk pemenuhan kebutuhan pangan dalam negeri adalah dengan swasembada pangan khususnya beras. Upaya Khusus (UPSUS) swasembada pangan telah dilaksanakan mulai tahun 2015-2017. Provinsi Jawa Timur merupakan salah satu provinsi penyangga pangan nasional. Produksi padi Jawa Timur tahun 2017 mencapai 13.060.464 ton. Sedangkan produksi padi Kota Blitar pada tahun 2017 sebesar 12.377 ton, dimana mengalami penurunan sebesar $24,8 \%$ dibanding tahun sebelumnya (BPS Jawa Timur, 2018). Adanya alih fungsi lahan pertanian merupakan salah satu sebab penurunan produksi padi di kota Blitar. Oleh karena itu produktivitas padi lebih diutamakan untuk terus dipacu.

Pengembangan teknologi pertanian diarahkan untuk meningkatkan kesejahteraan dan kemandirian masyarakatkhususnya petani. Alat dan mesin pertanian (alsintan) sebagai salah satu bentuk pengembangan teknologi pertanian mempunyai peranan yang sangat penting dan strategis dalam rangka mendukung pemenuhan produksi pertanian yang terus meningkat sejalan dengan pertambahan jumlah penduduk, menurunnya daya dukung lahan dan rendahnya intensitas pertanaman. Program mekanisasi pertanian sebagai bentuk pengembangan teknologi pertanian salah satunya dimaksudkan sebagai solusi untuk mengatasi sulitnyatenaga kerja di sektor pertanian. Adanya perubahan struktur demografi yang kurang menguntungkan, dimana petani berusia tua (lebih dari 55 tahun) jumlahnya semakin meningkat, sementara tenaga kerja usia muda semakin berkurang. Penyebab menurunnya minat tenaga kerja muda di sektor pertanian karena citra sektor pertanian yang kurang bergengsi dan kurang bisa memberikan imbalan memadai, cara pandang dan pandangan hidup tenaga kerja muda yang telah berubah di era perkembangan masyarakat postmodern. Krisis petani muda di sektor pertanian dan dominannya petani tua memiliki konsekuensi terhadap pembangunan sektor pertanian berkelanjutan, khususnya terhadap produktivitas pertanian, daya saing pasar, kapasitas ekonomi perdesaan, dan lebih lanjut hal itu akan mengancam ketahanan pangan serta keberlanjutan sektor pertanian. (Susilowati, 2016).

Berkurangnya tenaga kerja di sektor pertanian ini terlihat dalam Laporan Hasil Sensus Pertanian 2013, di mana jumlah 
rumah tangga usaha pertanian di Kota Blitar tahun 2013 tercatat sebanyak 4.938 rumah tangga. Angka tersebut menurun 49,35 persen dibandingkan tahun 2003 yang tercatat sebanyak 9.749 rumah tangga (Badan Pusat Statistik, 2013). Salah satu upaya pemecahan masalah kelangkaan tenaga kerja di sektor pertanian yang banyak terjadi di daerah, terutama untuk daerah kota kecil seperti Kota Blitar adalah melalui mekanisasi atau pemanfaatan alat mesin pertanian (alsintan). Program dari pemerintah terkait hal tersebut antara lain melalui program peningkatan sarana pertanian dengan memfasilitasi penyediaan sarana alat mesin pertanian.

Peningkatan produksi padi sebagai salah satu upaya pemenuhan kebutuhan pangan utama masyarakat dipengaruhi oleh fungsi produksi yang menyusun kegiatan usaha budidaya padi. Jumlah produksi usaha tani menyebabkan petani akan mendapatkan penerimaan dari kegiatan usahanya. Biaya mengambarkan bagaimana penggunaan faktor-faktor produksi (Soekartawi dkk, 2017). Perbedaan fungsi produksi yang digunakan sebelum dan setelah penggunaan alat dan mesin pertanian akan mempengaruhi pendapatan usaha tani padi, sehingga akan dapat dilihat perbandingan pendapatan petani padi sebelum dan setelah pemakaian alat dan mesin pertanian.

Karuga (2017) dalam penelitiannya menyimpulkan bahwa mekanisasi pertanian memiliki efek positif pada produksi jagung dan padi. Selain itu terdapat peningkatan yang signifikan terhadap jangkauan luasan area tanaman padi dan jagung. Sedangkan Widiastuti (2014) menyimpulkan bahwa program mesin pertanian dapat membantu meningkatkan pendapatan petani padi selain itu hasil analisis menunjukkan bahwa luas lahan dan penggunaan pupuk berpengaruh terhadap produksi padi, sedangkan jumlah benih tidak berpengaruh terhadap produksi.

Mekanisasi melalui penggunaan alat mesin pertanian di Kota Blitar merupakan salah satu cara untuk meningkatkan produksi dan pendapatan usahatani padi untuk mendukung pembangunan pertanian yang berkelanjutan. Terkait hal tersebut, maka perlu dilakukan penelitian untuk mengetahui proses mekanisasi dan menganalisis dampak dari mekanisasi pertanian terhadap pendapatan usaha tani padi (on farm) di Kota Blitar yang bermanfaat sebagai masukan untuk merumuskan kebijakan dan startegi pengembangan pertanian di Kota Blitar.

\section{Metode Penelitian}

Jumlah sampel yang diambil sebanyak 50 sampel dari petani padi di Gapoktan Sidomulyo Kecamatan Sananwetan Kota Blitar. Penelitian dilakukan pada bulan Pebruari - April 2019. Metode pengambilan data dilakukan dengan kusioner, wawancara, observasi dan studi kepustakaan.

\section{Analisis Data}

Biaya usaha tani meupakan biaya yang dikeluarkan oleh petani dalam proses usahatani dengan tujuan untuk memperoleh manfaat dari usahatani tersebut. Pendapatan kotor usahatani didefinisikan sebagai nilai produk total usahatani dalam jangka waktu tertentu, baik yang dijual maupun yang tidak dijualSedangkan pendapatan bersih usahatani adalah selisih antara pendapatan kotor dan pengeluaran total usahatani.. Pengeluaran total usahatani adalah nilai semua masukan yang habis dipakai atau dikeluarkan dalam produksi. Pendapatan bersih usahatani mengukur imbalan yang didapat oleh petani dari penggunaan faktor-faktor produksi kerja, pengelolaan, dan modal milik sendiri atau modal pinjaman yang diinvestasikan ke dalam usahatani (Soekartawi, dkk ,2017).

Analisis biaya dilakukan dengan menggunakan pendekatan income approach dimana pada pendekatan ini pendapatan dapat dibedakan ke dalam dua hal, yaitu pendapatan kotor dan pendapatan bersih. Pendapatan kotor memiliki pengertian yang sama dengan penerimaan, yaitu jumlah produk yang dihasilkan pada suatu periode produksi dikalikan dengan harga per satuan produk tersebut. Pendapatan kotor dapat diperhitungkan dengan rumus : 
$\mathrm{TR}=\mathrm{Py} \cdot \mathrm{y}$

Dimana :

$\mathrm{TR}=$ Total revenue (pendapatan kotor total)

Py $=$ Harga produksi (Rp./Kg)

$\mathrm{y}=$ Jumlah produksi (Rp.)

Pendapatan bersih dalam usahatani merupakan selisih antara nilai output dengan semua biaya yang dikeluarkan secara nyata (TC eksplisit) dalam suatu periode produksi. Pendapatan bersih ini diperhitungkan dengan menggunakan rumus:

$\mathrm{NR}=\mathrm{TR}-\mathrm{TC}$ eksplisit

Dimana :

$\mathrm{NR}=$ Pendapatan Bersih (Rp.)

$\mathrm{TR}=$ Total penerimaanyang diperoleh dari usaha tani(Rp.)

$\mathrm{TC}=$ Biaya total (Rp.)

(Suratiyah, 2015)

Faktor-faktor yang mempengaruhi

petani dalam penggunaan mekanisasi disajikan secara deskriptif sesuai dengan hasil wawancara dan observasi kepada responden.

Pengambilan kesimpulan hipotesis masukan dan biaya usaha tani padi menggunakan uji beda Mann Whitney sebagai berikut :

$\mathrm{H} 0: \mu 1=\mu 2$

$\mathrm{H} 1: \mu 1 \neq \mu 2$

Dengan formulasi sebagai berikut :

$$
\begin{array}{r}
Z=\frac{U-\frac{n_{1} \cdot n_{2}}{2}}{\sqrt{\frac{n_{1} \cdot n_{2} \cdot\left(n_{1}+n_{2}+1\right)}{\left.n_{1}+1\right)}} \frac{12}{2} \sum R_{1}} \\
U_{2}=n_{1} \cdot n_{2}+\frac{n_{1}}{2}-\sum R_{2}
\end{array}
$$

Dalam uji mann-whitney ini di bantu dengan aplikasi SPSS 20.0 dimana pengambilan keputusan hipotesis adalah :

1. jika $Z$ hitung $<Z$ tabel dan nilai sig $>$ 0,05 maka $\mathrm{HO}$ diterima

2. jika $Z$ hitung $>Z$ tabel dan nilai sig $<$ 0,05 maka $\mathrm{H} 0$ di tolak dan terima $\mathrm{H} 1$

Untuk mengetahui dampak makanisasi terhadap produksi dan pendapatan usaha tani padi dengan menggunakan analisis regresi linear berganda. metode Ordinary Least Square (OLS) model Cobb-Douglas (dibantu dengan aplikasi SPSS 20.2). Soekartawi,dkk (2017) menuliskan secara matematik bentuk persamaan analisis fungsi Cobb-Douglas sebagai berikut :

$Y=a X_{1}^{b 1}, X_{2}^{b 2}, \ldots \ldots . X_{n}^{b n} .10^{e}$

Fungsi

Cobb-douglas

ditransformasikan ke dalam bentuk logaritma untuk mendapatkan persamaan yang linier. Setelah diubah dalam bentuk Ln diperoleh persamaan regresi linier berganda sebagai berikut:

$\operatorname{Ln} N R=\operatorname{Ln} \beta_{0}+\beta_{1} \operatorname{LnX} X_{1}+\beta_{2} \operatorname{LnX} X_{2}+\beta_{3}$ $\operatorname{LnX}_{3}+\beta_{3} \operatorname{LnX} X_{3}+$

$\operatorname{LnX} X_{6}+\beta_{7} \operatorname{Ln} X_{7}$

$$
\beta_{4} \operatorname{LnX}_{4}+\beta_{5} \operatorname{LnX}_{5}+\beta_{5} \operatorname{LnX}_{5}+\beta_{6}
$$

$$
+\beta_{8} \mathrm{D}+\mathrm{e}
$$

Dimana :

NR = Pendapatan usaha tani

padi

$\beta_{0} \quad=$ konstanta

$\beta_{1}, \beta_{2}, \ldots \beta_{9}=$ koefisien regresi

$\mathrm{X}_{1}=$ harga bibit yang dinormalkan

dengan harga output (Rp.)

$\mathrm{X}_{2} \quad$ = harga tenaga kerja yang

dinormalkan dengan harga output (Rp.)

$\mathrm{X}_{3} \quad$ = harga pupuk urea yang

dinormalkan dengan harga output (Rp.)

$\mathrm{X}_{4} \quad=$ harga pupuk phonska yang

dinormalkan dengan harga output (Rp.)

$\mathrm{X}_{5} \quad$ = harga pupuk ZA yang

dinormalkan dengan harga output (Rp.)

$\mathrm{X}_{6} \quad$ = harga pestisida yang

dinormalkan dengan harga output (Rp.)

$\mathrm{X}_{7} \quad$ = luas lahan (m2)

$\mathrm{D}=$ variabel dummy, $1=$ menggunakan mekanisasi Penuh, 0 = menggunakan mekanisasi parsial

e $=$ error

\section{Hasil Dan Pembahasan}

\section{A. Kondisi Penggunaan Mekanisasi pada Usaha Tani Padi Di Kecamatan Sananwetan Kota Blitar}

Penelitian dilakukan di Kecamatan Sananwetan Kota Blitar yang terletak pada ketinggian rata-rata $156 \mathrm{~m}$ diatas permukaan air laut, dengan suhu rata-rata $29^{\circ}$ C. Luas wilayah Kecamatan 
Sananwetan yang mencapai $12,149 \mathrm{~km} 2$ dengan jumlah penduduk 57.509 jiwa. Kecamatan Sanawetan terdiri dari 7 kelurahan dengan lahan sawah seluas 411 hektar.

Penggunaan mekanisasi pada usahatani padi di Gapoktan Sananwetan Kota Blitar sebagain besar masih dilakukan secara parsial. Semua petani padi sudah menggunakan mekanisasi berupa hand tractor pada proses pengolahan tanah. Namun hanya sebagian kecil yang menggunakan mekanisasi pada proses tanam dan panen. Walaupun petani telah mengetahui tentang manfaat penggunaan alat dan mesin pertanian, namun masih enggan untuk menggunakannya. Adapun beberapa alasan yang dikemukakan adalah hasil kinerja mesin tanam dan panen dianggap masih belum maksimal sehingga membuat tingkat kepercayaan petani terhadap alat tersebut masih rendah, adanya rasa kemanusiaan untuk memberikan lapangan kerja bagi buruh tani, kurang memadahinya jumlah alat dan mesin pertanian yang tersedia serta belum berfungsinya UPJA di Gapoktan Sidomulyo, Kecamatan Sananwetan membuat penggunaan alsintan belum terorganisir dengan baik.

Demonstrasi alsintan melalui pelatihan kepada petani merupakan salah satu sarana dalam transfer teknologi terutama untuk pengenalan mekanisasi pertanian. Pelatihan dan demonstrasi penggunaan alsintan dapat dilakukan bekerjasama dengan pihak penyedia alsintan itu sendiri. Hasil penelitian Swastika (2012) menunjukkan bahwa untuk mempercepat adopsi teknologi maju pascapanen diperlukan beberapa alternatif kebijakan strategis, antara lain mengintensifkan introduksi promosi dan demonstrasi alat, serta mesin pascapanen melalui penyuluhan dan pelatihan di tingkat kelompok tani, memperbaiki harga pembelian gabah dan beras untuk memberi insentif bagi petani dan pedagang yang melakukan pengeringan, serta penyediaan kredit lunak dengan administrasi sederhana bagi perorangan atau perusahaan penyewaan alat dan mesin pascapanen.
Dari hasil wawancara didapatkan bahwa salah satu pertimbangan petani tidak menggunakan rice transplanter dan combine harvester karena dari pengalaman yang dlihat hasil dari mesin tersebut kurang memuaskan bagi mereka. Sebenarnya mereka mengetahui akan manfaat dari penggunaan rice transplanter maupun combine harvester namun pendapat positif tersebut tidak diikuti oleh sikap untuk menggunakannya. Petani berpendapat bahwa penggunaan alat tanam dari segi waktu dan jumlah tenaga kerja memang lebih efisien namun dari harga masih relatif lebih mahal dan tarifnya sering berubah - ubah. Keuntungan dari penggunaan mesin tanam meurut petani adalah meningkatkan ketepatan waktu penanaman dan waktu tanam menjadi lebih pendek (3-4 jam $/ 1000 \mathrm{~m} 2)$ serta mengurangi jumlah tenaga kerja, hanya dibutuhkan (1-2 orang per satu alat). Sedang kelemahan mesin tanam (rice transplanter) adalah harga sewa lebih mahal untuk lahan sempit, operator belum terampil, seringkali tidak bisa mejangkau tempat/lokasi yang jauh kedalam areal persawahan dan masih ada bagian lahan kosong sehingga harus dilakukan tambal sulam. Untuk penggunaan mesin pemanen (combine harvester) menurut petani keuntungan yang didapat adalah waktu untuk panen sangat singkat sehingga petani dapat menerima penghasilan lebih cepat, mengurangi kehilangan gabah (kerugian), sehingga bisa menghasilkan lebih banyak dan bersih dengan nilai jual lebih tinggi dibanding (rata-rata lebih tinggi Rp. $200 / \mathrm{kg}$ ), biaya panen tidak tergantung produktivitas padi diproduksi demikian bahwa petani dapat memperkirakan pendapatan mereka. Sedangkan kelemahan dari penggunaan mesin pemanen (combine harvester) adalah mesin ini besar dan berat sehingga tidak semua bagian lahan bisa tejangkau, dinilai membuat tanah menjadi keras sehingga mempersulit saat proses pengolahan tanah berikutnya, hanya bisa digunakan untuk tanaman yang normal/tegak, hasil yang didapat sangat tergantung oleh ketrampilan operator dan belum tersedianya jalan pertanian yang 
memadahi sehingga lahan sawah yang terletak di bagian dalam/tenggah sangat sulit untuk menerapkan mesin panen ini.

Chi (2010) dalam penelitiannya mengungkapkan bahwa faktor penting yang mempengaruhi penggunaan mekanisasi panen dan pascapanen adalah pendidikan dan persepsi petani terhadap mesin, teknis pelatihan, permodalan, metode penyuluhan, pengetahuan penyuluh, sistem informasi, infrastuktur dan luas lahan. Pendapat yang dikemukakan seseorang belum tentu mencerminkan sikap yang sesungguhnya. Sedangkan persepsi adalah penilaian sesorang berdasarkan pengalamannya terhadap obyek yang dialaminya. Sehingga membangun pesepsi yang positif pada petani dalam penggunaan mekanisasi sangatlah penting. Hal tersebut dapat dilakukan dengan meningkatkan pengetahuan yang bisa menstimulasi petani untuk mau mencoba menggunakan alsintan yang pada akhirnya bisa memberikan pengalaman yang memuaskan sehinga membangun persepsi yang positif tentang mekanisasi. Dalam hal ini peran penyuluhan pertanian tidak bisa diabaikan untuk merubah perilaku petani, menumbuhkan sikap atau persepsi positif terhadap suatu inovasi atau program pembangunan pertanian, meningkatkan pengetahuan dan ketrampulan petani terhadap suatu inovasi yang diberikan kepada petani (Van Den Ban dan Howkins ,1999).

Masih kurang memadahinya jumlah alsintan terutama rice tranplanter dan combine harveser juga tenaga operator yang terampil membuat petani merasa kawatir tidak mencukupi apabila musim tanam maupun panen serentak. Jumlah kebutuhan dan kesesuaian alsintan perlu didukung juga oleh kebijakan pemerintah, pendidikan, dan teknologi yang diadopsi. Azas enam tepat (jumlah, jenis, tempat, waktu, harga dan kualitas) juga seharusnya diimplementasikan dalam mengakses alsintan, jumlah sesuai dengan kapasitas dan luasan lahan garapan, jenis sesuai dengan peruntukan kegiatan yang dilakukan, tempat atau lokasi semakin dekat maka cenderung semakin mudah diakses (Purwantini dan Susilowati, 2017). Dengan luas lahan sebesar 411 ha jumlah alsintan terutama combine harvester dan rice transplanter masih belum mencukupi. Ketersediaan alsintan yang masih kurang dan belum berfungsinya UPJA membuat penggunaan mekanisasi pada budidaya padi belum optimal. Oleh karenanya keberadaan UPJA harus segera di fungsikan mengingat UPJA adalah wadah untuk mengelola alat dan mesin pertanian yang dikuasai oleh kelompok agar memberi manfaat bagi anggota kelompoknya.

Keputusan petani responden dalam penggunaan alsintan juga dipengaruhi oleh adanya kekawatiran tidak mendapatkan tenaga kerja pada musim tanam dan panen. Dalam penggunakan rice tranplanter, selain rasa kemanusiaan untuk tetap memberikan lapangan pekerjaan kepada buruh tani, keputusan petani lebih dipengaruhi oleh persepsi terhadap hasil kinerja mesin yang tidak memuaskan. Hasil penggunaan rice tranplanter menunjukkan penanaman untuk posisi pinggir kurang begitu maksimal sehingga petani masih harus membayar tenaga untuk pembenahan (sulam). Dari wawancara dengan buruh tanam didapatkan bahwa sebenarnya tidak ada kekawatiran tentang tergesernya lapangan pekerjaan mereka dengan penggunaan alsintan. Hal tersebut dikarenakan buruh tanam adalah perempuan dengan usia rata-rata 50 tahun keatas bahkan ada yang berusia 80 tahun. Mereka bekerja dalam grup yang terdiri dari 3-4 orang dan dibayar secara borongan sehingga upah yang didapat dibagi rata dalam grup tersebut. Tidak adanya tenaga baru membuat mereka sudah mempersiapkan diri dengan mendapatkan pekerjaan lain lebih nyaman dengan hasil yang sama. Dengan kata lain untuk saat ini menjadi buruh tanam bukan merupakan pekerjaan tetap namun hanya pekerjaan musiman. Alasan mereka bersedia melakukan pekerjaan tersebut karena masih banyak petani yang membutuhkan tenaga tanam secara manual. Perubahan yang terjadi di bidang ketenagakerjaan pertanian, terdapat kecenderungan menurunnya minat angkatan kerja muda untuk bekerja di pertanian dan munculnya fenomena 
'aging' dalam struktur tenaga kerja pertanian (Susilowati,dkk. 2010).

Makin langkanya tenaga kerja pertanian (buruh tani), seharusnya mendorong digunakannya alsintan dalam berbagai tahapan kegiatan pekerjaan di pertanian termasuk dalam usahatani padi. Dalam teori ekonomi disebutkan bahwa apabila terdapat permintaan (demand) dan penawaran (supply) yang saling bertemu akan terbentuk satu titik pertemuan yang dinyatakan dalam satuan harga dan kuantitas (jumlah barang). Dalam setiap transaksi pasti ada permintaan, penawaran, harga dan kuantitas yang saling mempengaruhi satu sama lain. Salah satu faktor yang mempengaruhi permintaan barang/jasa adalah perilaku konsumen/selera konsumen (Sukirno, 2010). Masih adanya permintaan petani terhadap buruh tanam karena dianggap hasilnya lebih memuaskan dan memenuhi rasa kemanusiaan daripada menggunakan mesin tanam, membuat keberadaan buruh tanam masih dibutuhkan sampai dengan sekarang.

Lain halnya dalam proses panen, selain karena alasan kemanusiaan adanya perilaku yang kurang meyenangkan dan berpotensi menimbulkan konflik menjadi, membuat petani masih menggunakan tenaga manusia. Agar tetap ada hubungan baik dengan para buruh tersebut petani enggan untuk menggunakan combine harvester. Bahkan apabila menggunakan combine harvester, petani masih menyisakan sebagian lahannya agar tetap bisa di panen secara manual. Berbeda dengan buruh tanam, pembayaran buruh panen menggunakan sistem bawon antara 8:1 sampai dengan 10:1. Dari hasil wawancara diketahui bahwa sistem bawon ini sangat menguntungkan bagi para buruh tanam. Dari hasil 'derep' ini selain dijual juga digunakan sebagai cadangan pangan untuk dikonsumsi sehari-hari. Dalam satu kali musim panen para pekerja ini dapat mengumpulkan gabah rata-rata 1 ton per orang. Masih menjanjikannya hasil yang didapat membuat pekerjaan ini masih menjadi salah satu pekerjaan utama. Para pekerja panen ini rata-rata adalah laki-laki dengan usia $35-60$ tahun. Mereka berkerja dalam grup yang terdiri dari 4-5 orang dengan dibantu 1 mesin perontok padi.

Hasil kajian Susilowati dan Purwantini (2017) menyimpulkan bahwa adopsi teknologi mekanisasi dalam kegiatan panen lebih efisien baik dari sisi tenaga kerja, biaya maupun waktu. Selain itu juga mengurangi kehilangan hasil. Dampak negatifnya adalah sebagian buruh tani kehilangan kesempatan kerja, berkurangnya bagian (upah) buruh tani dalam sistem bawon yang berlaku setempat. Untuk mengatasi dampak negatif berkurangnya kesempatan kerja bagi pembawon maka diperlukan fasilitasi untuk tumbuhnya alternatif kesempatan kerja bagi buruh yang terdampak oleh penggunaan alsintan tersebut. Selain itu, perubahan usahatani ke arah mekanisasi pertanian tersebut juga harus mempertimbangkan tatanan kelembagaan dan ketenagakerjaan setempat agar dapat tetap berjalan dengan saling menguntungkan. Perngembangan mekanisasi pertanian di Indonesia menganut azas mekanisasi pertanian selektif, yaitu mengintroduksi alat dan mesin pertanian yang disesuaikan dengan kondisi daerah setempat terutama karena dengan melihat ketersediaan tenaga kerja diwilayah setempat (Adillah, 2016). Hal ini agar tidak terjadi penganguran sehingga perlu dipikirkan solusi bersama agar tujuan dari menggunaan mekanisasi ini dapat tercapai.

\section{B. Analisa Masukan dan Biaya Usaha Tani Padi}

Masukan/Input yang digunakan dalam budidaya padi terdiri dari fasilitas produksi dan tenaga kerja. Produksi fasilitas termasuk benih, pupuk, dan pestisida sementara tenaga kerja termasuk mulai dari pengolahan tanah, penanaman, pemeliharaan, dan panen. 
Tabel 1.

Perbandingan Jumlah Masukan/Input pada Budidaya Tanaman Padi

\begin{tabular}{lccc}
\hline \multicolumn{1}{c}{ Masukan (1000 m2) } & $\begin{array}{c}\text { Mekanisasi } \\
\text { Parsial }\end{array}$ & $\begin{array}{c}\text { Mekanisasi } \\
\text { Penuh }\end{array}$ & Sig (2-tailed) \\
\hline Benih (kg) & 3,43 & 3,27 & 0,354 \\
Pestisida (liter) & 0,3 & 0,29 & $\mathbf{0 , 0 4 9}$ \\
Pupuk Urea (kg) & 32,55 & 36,19 & 0,327 \\
Pupuk Phonska (kg) & 35,9 & 35,61 & 0,750 \\
Pupuk ZA (kg) & 15,14 & 16,76 & 0,304 \\
Tenaga Kerja (HOK) & 5,06 & 2,59 & $\mathbf{0 , 0 0 0}$ \\
\hline
\end{tabular}

Sumber : Data primer, dianalisa, 2019

Keterangan :

${ }^{*}=$ berbeda nyata/signifikan $(\alpha=5 \%)$

Dari Tabel 1 dapat dilihat bahwa ada perbedaan dalam kuantitas input digunakan oleh petani yang menggunaan mekanisasi secara parsial dan mekanisasi secara penuh. Dalam penggunaan benih, perbedaan tidak bermakna secara nyata (Nilai $p>0.05$ ). Hal ini disebabkan karena cara tanam secara manual memungkinkan penggunaan bibit oleh masing-masing pekerja tidak sama tergantung keterampilan masing-masing pekerja. Sedangkan bila menggunakan mesin tanam padi, jumlah bibit yang ditanam harus sesuai standar persyaratan teknis yang telah ditetapkan.

Penggunaan pupuk kimia seperti urea, ponska, dan ZA tidak berbeda secara nyata antara petani yang menggunakan mekanisasi secara parsial dan mekanisasi secara penuh. Penggunaan pupuk lebih cenderung tergantung pada kesenangan dan pengetahuan masing-masing petani.

Dalam penggunaan pestisida, nilai $p$ $<0,05$ artinya perbedaan penggunaan pestisida oleh petani yang menggunakan mekanisasi secara penuh secara signifikan lebih rendah dari petani yang menggunakan mekanisasi secara manual. Dari hasil wawancara didapatkan bahwa petani yang menggunakan mekanisasi secara penuh lebih mengetahui dan menerapkan tentang penanggulangan hama terpadu, sehingga apabila serangan hama dan penyakit tanaman tidak terjadi atau masih bisa ditolerir (dibawah ambang batas ekonomi) tidak akan dilakukan aplikasi pestisida. Sedangkan petani lainnya walaupun tidak ada indikasi serangan hama dan penyakit penggunaan pestisida tetap dilakukan sebagai antisipasi.

Penerapan mekanisasi penuh secara nyata dapat mengurangi tenaga kerja seperti yang ditunjukkan pada Tabel 1. Dalam pekerjaan penanaman, tenaga kerja dibutuhkan untuk penanaman secara manual lebih besar dari pada dengan menggunakan mesin tanam. Dengan menggunakan cara manual, lahan seluas 1000 m2 menggunakan 3-5 tenaga kerja perempuan dengan 10-12 jam kerja, sementara dengan menggunakan mesin tanam (Transplanter) dibutuhkan 1-2 tenaga kerja pria plus mesin tanam yang membutuhkan waktu 3-4 jam. Dalam proses panen dengan menggunakan mesin panen (Combine Harvester) dibutuhkan tenaga kerja sebanyak 2 orang untuk luas lahan $1000 \mathrm{~m} 2$ dengan pembagian tugas satu orang sebagai pengemudi dan satu lagi sebagai pengumpul hasil. Waktu yang dibutuhkan berkisar dari 1 jam hingga 2 jam tergantung pada kondisi tanah dan tanaman. Sedangkan untuk panen dengan cara manual dibantu dengan alat perontok padi membutuhkan 4-5 orang untuk bekerja selama 10 - 12 jam. Panen dengan cara manual sangat rentan terhadap kerugian berat selain dikarenakan jumlah tenaga kerja dan jam operasional yang tinggi juga dikarenakan adanya biaya tambahan berupa pemberian makanan/konsumsi bagi para pekerja yang harusnya sudah termasuk dalam upah kerja. Khalili (2019) dalam penelitiannya menyebutkan bahwa dalam sistem semi-mekanisasi biaya rata-rata tenaga kerja manusia dan benih sekitar 
$60 \%$ lebih tinggi dari sistem mekanisasi. Penelitian Amare dan Endalew (2016) menunjukkan bahwa penggunaan alsintan panen dan pascapanen menurunkan penggunaan tenaga kerja manusia, dengan menggunakan combine harvester akan menggantikan kebutuhan tenaga kerja manusia untuk panen dan perontokan.

Tabel 2.

Perbandingan rerata biaya /1000 m2

\begin{tabular}{lcccc}
\hline Biaya & $\begin{array}{c}\text { Mekanisasi parsial } \\
(\mathrm{Rp} .)\end{array}$ & $\begin{array}{c}\text { Mekanisasi penuh } \\
(\text { Rp.) }\end{array}$ & Selisih & Sig. (2-tailed) \\
\hline Pengolahan Tanah & 169.304 & 164.500 & 4.804 & 0,842 \\
Tanam & 180.402 & 187.851 & $(7.449)$ & 0,781 \\
Pupuk & 266.088 & 260.294 & 5.794 & 0,853 \\
Pestisida & 70.908 & 76.081 & $(5.174)$ & 0,104 \\
Panen & 311.026 & 253.750 & 57.276 & $0,000^{*}$ \\
Sewa lahan & 716.912 & 751.984 & $(35.072)$ & 0,054 \\
\hline Total Biaya & $\mathbf{1 . 7 4 6 . 7 9 3}$ & $\mathbf{1 . 7 2 4 . 4 0 7}$ & $\mathbf{2 2 . 3 8 6}$ & $\mathbf{0 . 3 5 4}$ \\
\hline
\end{tabular}

Sumber : Data primer, dianalisa, 2019

Keterangan : ${ }^{*}=$ berbeda nyata/signifikan $(\alpha=5 \%)$

Pada tabel. 2, dari total biaya pertanian ada perbedaan biaya yang dikeluarkan petani menggunakan mekanisasi penuh dan menggunakan mekanisasi parsial. Total biaya penggunaan mekanisasi parsial lebih tinggi dari penggunaan mekanisasi secara penuh. Dari perbedaan biaya pertanian, perbedaan besar terjadi dalam biaya panen, sementara di sisi lain biayanya relatif sama atau tidak berbeda secara signifikan.

Biaya rata-rata penanaman padi dengan menggunakan cara manual adalah Rp 180.402,00 per $1000 \mathrm{~m}^{2}$ sedangkan petani yang menerapkan menggunakan mesin tanam (Rice Tranplanter) adalah Rp. 187.851 per 1000 $\mathrm{m}^{2}$. Hal ini disebabkan biaya operator dan sewa alat relatif lebih mahal. Alat tanam ini jumlahnya dalam 1 (satu) kecamatan hanya ada 2 (dua) unit dengan operator sebanyak 2 orang. Umar dan Pangaribuan (2017) dalam penelitiannya menyimpulkan bahwa penggunaan transplanter jarwo mampu menghemat penggunaan tenaga kerja secara signifikan dibanding cara konvensional. Efisiensi penggunaan tenaga kerja dengan mesin transplanter jarwo di lahan pasang surut sebesar $80,43 \%$.

Saat panen, cara manual dengan dibantu mesin perontok juga meningkatkan biaya. Tabel 2 menunjukkan bahwa penggunaan mesin panen lebih murah dibandingkan dengan cara manual. Biaya penggunaan mesin panen (Combine Harvester) adalah $\mathrm{Rp}$. $250.000,00$ - 275.000,00 per $1000 \mathrm{~m}^{2}$. atau setara dengan bawon 1:12. Sedangkan panen manual dibantu dengan mesin perontok biaya yang dikeluarkan adalah bawon dari 1: 9 ke 1: 10. Bawon adalah upah diberikan untuk memanen tenaga kerja dalam bentuk gabah. Misalnya jika 1: 9, maka dari 9 kwintal gabah hasil panen diperoleh upah 1 sekarung gabah. Dari upah tersebut petani pengguna jasa masih memberi tambahan makan dengan alasan kemanusiaan yang akhirnya secara tidak langsung menambah besaran biaya panen.

Dari hasil Uji Mann-Whitney menggunakan aplikasi SPSS versi 20.0 pada Tabel 2, menunjukkan bahwa nilai signifikansi hanya terdapat pada biaya panen dengan nilai $\mathrm{P}$ adalah $0.000<0,05$. Ini menunjukkan bahwa $\mathrm{H} 1$ diterima dan HO ditolak, dan kesimpulannya adalah adanya perbedaan yang signifikan pada biaya panen menggunakan mesin panan (combine harvester). Praweenwongwuthi, dkk (2010) dalam penelitiannya menyimpulkan bahwa kebutuhan tenaga kerja panen secara manual lebih di tinggi dibandingkan dengan menggunakan combine harvester. Sedangkan dari segi biaya, panen secara manual 
membutuhkan biaya lebih tinggi dan memberikan laba kotor lebih rendah dibandingkan menggunakan combine harvester.

Analisis total biaya pertanian dengan Uji Mann-Whitney, signifikansi nilai pada total biaya pertanian adalah 0,354 (> $0,05)$. Ini menunjukkan bahwa $\mathrm{HO}$ diterima dan $\mathrm{H} 1$ ditolak, dan kesimpulannya adalah bahwa tidak ada perbedaan yang signifikan dalam total biaya pertanian antara penggunaan mekanisai parsial dan mekanisasi penuh.

\section{Pengaruh Mekanisasi Terhadap Pendapatan Usaha Tani Padi}

Untuk mengetahui apakah ada pengaruh signifikan dari penggunaan mekanisasi secara parsial dan penuh terhadap pendapatan usaha tani digunakan analisis regresi linier berganda. Model ini telah lulus uji asumsi klasik yaitu normalitas, autokorelitas, dan uji heteroskedastisitas.

Tabel 3.

Hasil Regresi Linear Berganda

\begin{tabular}{lrc}
\hline Variabel & Koefisien & t stat \\
\hline Konstanta & $-3,838 \mathrm{~ns}$ & $-4,239$ \\
Harga benih dinormalkan (X1) & $-0,285^{*}$ & $-2,22$ \\
\hline Harga tenaga kerja dinormalkan (X2) & $-0.006 \mathrm{~ns}$ & -0.015 \\
\hline Harga pupuk urea dinormalkan (X3) & $-0,056 \mathrm{~ns}$ & $-0,948$ \\
\hline Harga pupuk phonska dinormalkan (X4) & $-0,121 \mathrm{~ns}$ & $-1,789$ \\
\hline Harga pupuk ZA dinormalkan (X5) & $0,053 \mathrm{~ns}$ & 1,069 \\
\hline Harga pupuk pestisida dinormalkan (X6) & $-0,053 \mathrm{~ns}$ & $-0,697$ \\
\hline Luas lahan (m2) (X7) & $1,532^{*}$ & 3,757 \\
\hline Dummy mekanisasi (0=mekanisasi parsial, 1 & $0.258^{*}$ & 3,170 \\
$=$ mekanisasi penuh) (D) & & \\
\hline F & $122,764^{*}$ \\
Adjusted R2 & 0,952 \\
\hline
\end{tabular}

Sumber : Data primer, dianalisa, 2019

Keterangan : ${ }^{*}=$ berbeda nyata $(\alpha=5 \%)$

Fungsi Cobb Dougglas menggunakan regresi linear berganda dapat di tunjukkan sebagai berikut :

Ln NR = Ln -3.838 - 0,285Ln X1-

$0,056 \operatorname{LnX} 2-0,121 \operatorname{LnX} 3+$

$0.053 \operatorname{Ln} X 4-0,056 \operatorname{Ln} X 5-$

$0.006 \operatorname{LnX} 6+1,532 \operatorname{LnX} 7+0,258 \mathrm{D}+\mathrm{e}$

Hasil analisis regresi linier berganda pada Tabel 3 menunjukkan bahwa variabel luas tanah, harga benih dan jenis mekanisasi miliki berpengaruh signifikan terhadap pendapatan usahatani, sedangkan variabel lain yaitu harga pupuk urea, harga pupuk ponska, harga pupuk ZA dan harga pestisida tidak memiliki efek signifikan. Koefisien determinasi (adjusted $R 2$ ) yang didapat senilai 0,952 yang menunjukkan bahwa proporsi pengaruh variabel bebas terhadap variabel terikat sebesar $95,2 \%$.

Luas lahan memiliki koefisien 1,532 dengan nilai signifikansi 0,001 yang berarti kurang dari 0,01 atau kepercayaan 99\% tingkat. Ini menunjukkan bahwa lahan tersebut memiliki pengaruh signifikan terhadap pendapatan pertanian. Koefisien memiliki nilai positif yang berarti luas lahan dan pendapatan usahatani padi positif korelasi. Jika luas lahan bertambah $1 \%$ itu akan meningkatkan produksi beras $1,532 \%$. Ini karena luas lahan yang lebih besar, semakin banyak tanaman yang bisa ditanam itu akan meningkatkan pendapatan pertanian. Hasil ini sejalan dengan penelitian Kusnadi, dkk (2011), bahwa luas lahan berpengaruh signifikan pada produksi beras di lima provinsi beras pusat penghasil yaitu Sumatera Utara, Jawa Barat, Jawa Tengah, Jawa Timur, dan Sulawesi Selatan. Dengan adanya peningkatan hasil produksi maka pendapatan petani juga meningkat. Penelitian Arif, dkk (2018) menyebutkan bahwa luas lahan berpengaruh sigifikan pada pendapatan usaha tani padi di 
bawah program UPJA di Kecamatan Prambanan Kabupaten Sleman.

Harga benih organik memiliki nilai koefisien signifikan -0,285 pada tingkat kepercayaan 95\%. Ini menunjukkan bahwa harga benih secara signifikan berpengaruh pada pendapatan pertanian. Koefisien memiliki nilai negative yang artinya harga benih dan pendapatan memiliki korelasi negatif. Jika harga benih meningkat sebesar 1\% maka akan menurunkan pendapatan bertani sebesar $0,285 \%$. Semakin tinggi harga benih menunjukkan penggunaan benih juga meningkat. Penggunaan benih yang berlebihan akan menyebabkan jumlah populasi melebihi kapasitas lahan dan mempengaruhi perkembangan tanaman padi sehingga pertumbuhannya menjadi kurang optimal. Pada penelitian Kumalasari, Sudiarso dan Suryanto tentang Pengaruh Jarak Tanam dan Jumlah Bibit Pada Tanaman Padi (Oryza
L) Hibrida Varietas PP3 di Kabupaten Pasuruan menunjukkan bahwa jarak tanam dan jumlah bibit berpengaruh terhadap hasil gabah per hektar dimana jumlah bibit $1 /$ lubang memberikan hasil produksi gabah kering panen paling tinggi yaitu 9,92 ton/ha.

Penggunaan mekanisasi memiliki signifikan pada tingkat kepercayaan 95\% dengan nilai koefisien 1,532 yang berarti mekanisasi penuh memiliki pengaruh yang signifikan dan memiliki korelasi positif pendapatan usaha padi. Pendapatan pertanian dari petani yang menggunakan mekanisasi secara penuh mulai pengolahan tanah sampai dengan panen lebih tinggi daripada petani yang hanya menggunakan mekanisasi secara persial (olah tanah). Penelitian Arif, dkk (2018) menyebutkan mekanisasi berpengaruh nyata/sigifikan dan berpengaruh positif terhadap pendapatan usaha tani padi.

Tabel 4.

Perbandingan Rata-Rata Pendapatan Usaha Tani /1000 m2

\begin{tabular}{lccc}
\hline Uraian & $\begin{array}{c}\text { Mekanisasi parsial } \\
\text { (Rp.) }\end{array}$ & $\begin{array}{c}\text { Mekanisasi penuh } \\
\text { (Rp.) }\end{array}$ & $\begin{array}{c}\text { Sig. } \\
(2-\text {-tailed) }\end{array}$ \\
\hline Produktivitas & 682,87 & 782,15 & $0.000^{*}$ \\
(kg/1000m2) & & & \\
Penerimaan (Rp.) & 2.868 .047 & 3.285 .035 & $0.001^{*}$ \\
Pengeluaran (Rp.) & 1.714 .640 & 1.694 .460 & 0.177 \\
Pendapatan (Rp.) & $\mathbf{1 . 1 5 3 . 4 0 7}$ & $\mathbf{1 . 5 9 0 . 5 7 4}$ & $0.006^{*}$ \\
\hline
\end{tabular}

Sumber : Data primer, dianalisa, 2019

Keterangan : * berbeda nyata $(\alpha=5 \%)$

Pendapatan adalah pendapatan bersih yang bisa dihasilkan oleh petani dalam kegiatan pertanian. Dari hasil analisis pendapatan yang ditunjukkan pada Tabel 4, dapat dilihat bahwa produktiitas (kwt/1000m2) dari pertanian petani yang menerapkan mekanisasi secara penuh lebih tinggi daripada petani yang menerapkan mekanisasi secara parsial. Uji Mann-Whitney menunjukkan hasil yang didapat berbeda secara nyata pada tingkat signifikan $5 \%$. Penerimaan (Rp./1000m2) yang diterima petani lebih tinggi bila menggunakan mekanisasi secara penuh dan berbeda secara nyata pada tingkat signifikansi $5 \%$.
Untuk biaya yang dikeluarkan per 1000m2 pada penggunaan mekanisasi secara parsial lebih tinggi namun tidak berbeda secara nyata dengan penggunaan mekanisasi secara penuh. Pendapatan usaha tani padi selain dilihat dari produktivitas juga dari pendapatan bersih yang didapatkan. Dari tabel 4 diatas dapat dilihat bahwa pendapatan bersih petani dengan menggunakan mekanisasi secara penuh lebih tinggi dan berbeda secara nyata dibandingkan dengan menggunakan mekanisasi secara parsial. Ini sejalan dengan kajian yang dilakukan oleh Purwantini dan Susilowati (2017) bahwa adopsi teknologi mekanisasi dalam kegiatan panen lebih efisien baik dari sisi 
tenaga kerja, biaya maupun waktu. Selain itu juga mengurangi kehilangan hasil. Basu, D dan Nandi, AK (2014) menyatakan bahwa penggunaan mesin dalam produksi pertanian memainkan peran penting dalam peningkatan produktivitas dan pengurangan biaya unit produksi sehingga menghasilkan pertanian yang menguntungkan dan layak.

\section{Kesimpulan}

Hasil penelitian dan pembahasan yang telah dilakukan terhadap mekanisasi padi di Gapoktan Sidomulyo Kecamatan Sananwetan, Kota blitar dapat diambil kesimpulan bahwa

a. Penerapan mekanisasi pada budidaya padi masih bersifat parsial yaitu kebanyakan hanya pada proses pengolahan tanah, karena kurangnya jumlah alsintan, adanya rasa kemanusiaan dalam pemberian kesempatan kerja pada buruh tani serta belum berfungsinya UPJA secara optimal.

b. Jumlah benih (kg), luas lahan (m2) dan tenaga kerja (HOK) secara signifikan menunjukkan perbedaan antara petani yang menggunakan mekanisasi secara parsial dan petani yang menggunakan mekanisasi secara penuh. Sedangkan hanya pada proses panen biaya yang dikeluarkan menunjukkan perbedaan yang signifikan antara penggunaan mekanisasi secara parsial dan mekanisasi secara penuh.

c. Besar biaya benih (Rp.), luas lahan (m2) dan penggunaan mekanisasi berpengaruh secara nyata terhadap pendapatan petani padi.

\section{Daftar Pustaka}

Ajao, A.O., Ajetomobi, J.A., dan Olarinde, L.O. 2005. Comparative Efficiency of Mechanized and NonMechanized Farms in Oyo State of Nigeria: $A$ Stochastic Frontier Approach. J. Hum. Ecol., 18 (1): 27-30.

Aldillah, Rizma. 2016. Kinerja Pemanfaatan Mekanisasi Pertanian dan Implikasinya Dalam Upaya Percepatan Produksi
Pangan di Indonesia .http://ejurnal.litbang.pertanian.go.i d/index.php/fae/article/view/8663

Amare D, Endalew W. 2016. Agricultural Mechanization: Assessment of Mechanization Impact experiences on The Rural Population and The Implications for Ethiopian Smallholders. Engineering and Applied Sciences. 1(2): 39-48.

Arif, K.,Irham.,Hardyastuti,S. 2018. Dampak Mekanisasi Melalui Program Upja Terhadap Pendapatan Usaha Tani Padi di Kecamatan Prambanan Kabupaten Sleman. Agro Ekonomi, Vol.29,No.1, Juni 2018, HI. 132145. UGM.

BPS. 2013. Potret Usaha Pertanian Kota Blitar menurut Subsektor 2013.BPS Kota Blitar.

BPS. 2018. Produksi Padi Menurut Kabupaten/Kota di Jawa Timur Tahun $2007 \quad$ - 2017. https://jatim.bps.go.id/statictable/20 18/10/31/1340/produksi-padimenurut-kabupaten-kota-di-jawatimur--ton---2007-2017.

Basu, Dipika dan Nandi, Arun Kr. 2014. Farm Mechanisation and Rationality of Labour Use in Indian Agriculture: A Frontier Analysis of Cost of Cultivation Data.Indian Journal of Agricultural Economics. Vol.69, No.3, July-Sept. 2014

Chi TTN. 2010. Factors Affecting Mechanization in Rice Harvesting and Drying in The Mekong Delta, South Viet Nam. Omonrice [Internet]. Available from: http://clrri.org/ver2/uploads/noidung 117-20.pdf

Karuga, Joseph.2017. Impact of Farm Mechanization on Crop Production and Yields: Case of interventions implemented under ASDP $I$. Strategic Alliance and Knowledge Support System (ReSAKSS). http://hdl.handle.net/20.500.12018/ 2789

Khalili, MA.,Rostamian,R.,Troujeni,ME dan Moghaddam,AK.2019.Economic Of Mechanized and Semi-Mechanized Rainfed Wheat Production Systems Using Multiple Linear 
Regression Model.Information Processing In Agriculture. China Agricultural University. Production and hosting by Elsevier B.V. on behalf of KeAi. https://doi.org/10.1016/j.inpa.2019. 06.002

Kumalasari, Septi Nuning.,Sudiarso,.dan Suryanto, Agus.2017.Pengaruh Jarak Tanam dan Jumlah Bibit Pada Tanaman Padi (Oryza L) Hibrida Varietas PP3. Jurnal ProduksiTanaman.Vol. 5 No. 7 , Juli2017 : 1220 - 1227. ISSN : $2527-8452$

Kusnadi, N., Tinaprilla, N., Susilowati, S.H., \&Purwoto, A. (2011). Analisis Efsiensi Usahatani Padi Di Beberapa Sentra Produksi Padi Di Indonesia. Jurnal Agro Ekonomi, 29(1), 25-48

Widiastuti, Prapti.2014. Dampak Mekanisasi Pertanian terhadap Pendapatan Petani Padi di Kabupaten Klaten (Studi pada UPJA Agawe Santoso Kecamatan Kalikotes). Tesis. Universitas Gadjah Mada. Yogjakarta.

Praweenwongwuthi,Sorat.,Laohasiriwong,

Suwit.,Rambo, Terry.2010. Impacts Of Rice Combine Harvesters on Economic and Social Of Farmers In a village of the Tung Kula Ronghai Region. Research Journal of Agriculture and Biological Sciences, 6(6):778-784. INSInet Publication

Soekartawi, Soeharjo,A.,Dillon, John L dan Hardaker, Brian. 2017. IImu Usaha Tani. Universitas Indonesia .Jakarta.

Suratiyah, K. 2015. IImu Usaha Tani.Penebar Swadaya.Jakarta

Purwatini, TB dan Susilowati, SH.,. 2017. Dampak Penggunaan Alat dan Mesin Panen Terhadap Kelembagaan Usaha Tani Padi. Analisis Kebijakan Pertanian, Vol. 16 No. 1 Juni 2018 hal. 73-88. DOI: http://dx.doi.org/10.21082/akp.v16n 1.2018.73-88

Susilowati, SH.2016. Fenomena Penuaan Petani dan Berkurangknya Tenaga Kerja Muda Serta Implikasinya
Bagi Kebijakan Pembangunan Pertanian.

ForumPenelitianAgroEkonomi,

Vol.34 No.1.Juli 2016 : 35-55. http://ejurnal.litbang.pertanian.go.id /index.php/fae/article/view/7310/64 46

Susilowati SH, Hutabarat B, Rachmat M, Sugiarto, Supriyati, Zakaria AK, Supriyadi H, Purwoto A, Supadi, Winarso $B$, lqbal $M$, Hidayat $D$, Purwantini TB, Elizabeth R, Muslim C, Nurasa T, Maulana M, Aldillah R. 2010. Indikator pembangunan pertanian dan perdesaan: karakteristik sosial ekonomi petani dan usaha tani padi. Laporan Hasil Penelitian. Bogor (ID): Pusat Analisis Sosial Ekonomi dan Kebijakan Pertanian.

Sukirno, Sadono. 2010. Mikroekonomi Teori Pengantar. Edisi-3. PT Raja Grafindo Persada. Jakarta.

Swastika DKS. 2013. Teknologi Panen dan Pascapanen Padi: Kendala Adopsi dan Kebijakan Strategi Pengembangan. Analisis Kebijak Pertan. 11(4):331-348

Umar, Sudirman dan Pangaribuan, Sulha. 2017. Evaluasi Penggunaan Mesin Tanam Bibit (Rice Transplanter) Sistem Jajar Legowo di Lahan Pasang Surut. Jurnal Teknis Pertanian Lampung, Vol. 6 No. 2:105-114.

Van Den Ban. A.W. dan H.S Hawkins., 1999. Penyuluhan Pertanian. Kanisius.Yogyakarta. 